\title{
Introduction to Vital Biological and Regenerative Factors Myxocyprinus asiaticus
}

\author{
Mohammad Forouhar Vajargah* \\ Department of Fisheries - Faculty of Natural Resources - University of Guilan, Iran \\ ${ }^{\star}$ Corresponding author: Mohammad Forouhar Vajargah, Department of Fisheries - Faculty of Natural Resources - University of Guilan; Iran; Email: \\ mohammad.forouhar@yahoo.com
}

Received: November 03, 2021; Accepted: November 10, 2021; Published: November 19, 2021

\begin{abstract}
It will not be possible to get the biological course and to know the biological species without a comprehensive knowledge of different species, especially their important species from different landscapes. Chinese high-fin banded shark is a species of biological and geogeological importance about which little resources and research have been done. This fish is also of special importance from an evolutionary point of view. The present article tries to examine the general characteristics, general needs, and methods required.
\end{abstract}

Keywords: Biological, Geogeological, Evolution

\section{Introduction}

Myxocyprinus asiaticus is a freshwater fish native to China and the only member of the family, Catostomidae, in Asia [1]. This species is an important commercial fish and has an important role in archaeological and geogeographical studies [2]. It is also used as an ornamental fish due to its colorful body. However, the wild population of this fish has decreased tragically in recent decades due to overfishing, water pollution and other anthropogenic effects [3]. Chinese sucker is an endangered species that is the second most endangered species in China [4].

\section{Systematic and Morphological}

It is the only member of the Catostomidae family in Asia [5]. A large freshwater fish with a slightly long and compact body on both sides, small and short head, short snout, and curved mouth upwards, full lateral line, lack of Barbel on jaw and smooth abdominal surface 48-53 scales on lateral line, long base of dorsal fin Which is close to the second fin. It has three stripes on the sides and a panda-like dark spot on the edge of the eye in adult species [6].

\section{Distribution}

They are distributed only in the Yangtze and Min Jiang rivers in China [7].

\section{Maintain and Expand Reserves}

This species is an endangered fish, which is in the second category of endangered aquatic and terrestrial animals in China [8].

Controlling abandoned populations and preventing population decline through factors such as disease is inevitable. One of the most reliable methods of disease control in aquaculture is the preventive use of immune stimulants [9]. Immune stimuli can increase survival against pathogens by enhancing the nonspecific defense mechanism [10]. Also, in a study on thermal marking of fish pebbles, which was performed by exposing Chinese high-fin banded shark larvae to temperature regimes from hot water $28^{\circ} \mathrm{C}$ to cold water $16^{\circ} \mathrm{C}$, it was found that the incremental patterns of pebbles were different in each group. In this way, by controlling the duration of presence in hot water, narrower or wider incremental patterns could be obtained. A deep and positive relationship between the width of the incremental pattern and the duration of cultivation in hot water in each cycle of water temperature fluctuation could be seen. Unusually, it is proposed as a solution to distinguish breeding people from species grown in nature [11]. Studies have also shown that those in the 24-hour temperature cycle provided clear, high-contrast patterns compared to constant-temperature findings [12].

\section{Genetics}

The Catostomidae family is thought to have evolved from a cyprinid-like ancestor in Asia [13]. Although most members of this family of about 60 species are now confined to North America, only two species include Catostomus catostomus rostarus (a subspecies of C. c. Catostomus in North America; sometimes both of these fish as a subspecies). Single species are classified as C. c. Catostomus in eastern Siberia and Myxocyprinus asiaticus in China, native to Eurasia. Tetraploidy has been confirmed in North American suckers [14,15]. A study also found that tetraploidy of this family was found in Asia and not in North America [16].

\section{Nutrition}

The Chinese high-fin banded shark actively collects food from the floor and seems to need 30 minutes to complete one dimension 
[17]. Chinese high-fin banded shark is an omnivorous species that is bred in China due to its delicious meat and uniform growth. These resources are difficult to store and easily reduce water quality and even spread diseases [18]. It is important to know the sources and principles of fish nutrition in their impact on various factors such as growth, productivity, survival and fertility, as well as providing alternative or complementary methods and food sources. Some important sources of nutrition will be listed.

\section{Phosphorus}

Phosphorus is an important component of the internal skeleton of fish, with more than one-third found in phospholipids, nucleic acids, cell membranes, and energy-rich compounds [19]. Although fish have the ability to absorb minerals from water [20], food is the main source of phosphorus due to its low concentration in salt and fresh water. Analyzes have shown that the minimum amount of phosphorus for optimal growth of this species of fish is 7.4 grams per kilogram of body mass [21]

\section{Protein}

Knowing the amount of protein needed is a necessity for formulating balanced diets. So far, only a few studies have been performed on Chinese suckling infants. Information [22,23] about the protein required in the diet of this fish is scarce. According to a study, about 460 grams per kilogram of body weight of protein fish in a diet Food can be the optimal level for the maximum growth of $M$. asiaticus [24]. In general, one of the main components of fish mixed foods is fish meal or fish meal, although recently the price of fish meal has increased sharply with a decrease in resources [25-28]. Therefore, the need to look for sustainable alternatives is felt. For decades, aquatic nutritionists have evaluated plant protein sources to replace some or all of fishmeal [29-32]. One of these alternatives is Soybean meal (SBM). According to research, fermented soybean meal (FSBM) is a plant protein suitable for replacing up to $35 \%$ of the protein in fish diet without significant adverse effects on growth, survival, FCR, PER and body composition [33].

\section{Vitamin C}

Vitamin C, also known as L-ascorbic acid, is a powerful reducing agent that facilitates iron absorption [34]. Vitamin $\mathrm{C}$ is also a cofactor in the hydroxylation of proline and lysine to hydroxyproline and hydroxy-lysine [35]. Research has shown that growth factors for nutritional survival and nutritional productivity are improved by adding vitamin $\mathrm{C}$ to food at a maximum of $2.125 \mathrm{mg}$ per kilogram of fish body weight. Also, the minimum amount of vitamin C for optimal growth of M. asiaticus is $84.6 \mathrm{~g} / \mathrm{kg}$ body weight of fish [36].

\section{Conclusion}

The importance and danger of this species makes it a species of interest. The importance of nutrition and disease prevention and policy for the population of this fish is well known. It is also noteworthy that this fish is a creature to follow the evolutionary path.

\section{References}

1. Nelson EM (1976) Some notes on the Chinese sucker. Copeia 3: 594-595.
2. Wang S, Yue PQ, Chen YY (1998) China red data book of endangered animals: pisces. Science Press, Beijing, China. 247. [In Chinese].

3. Zhang CG, Zhao YH, Kang JG (2000) A discussion on Resources status of Myxocyprinus asiaticus (Bleeker) and their Conservation and the recovery. J. Natl. Resour 2: 155-159.

4. Zhang, C. 2007. Microstructures of the liver and the gall Bladder of Myxocyprinus asiaticus. Journal of South-West University 29: 134-139.

5. Sattari M (2008) Ichthyology (2).

6. Chen Z (2005) the biological characteristic and breeding Technology of Chinese sucker, Myxocyprinus asiaticus. Fishery Guide to be Rich 22: 44-46 (in Chinese)

7. Gao Z, Li Y, Wang W (2008) Threatened fishes of the world: Myxocyprinus asiaticus Bleeker 1864(Catostomidae). Environmental Biology of Fishes 83 345-346.

8. Yalsuyi AM, Vajargah MF (2017) Recent advance on aspect of fisheries: A review. Journal of Coastal Life Medicine 5: 141-148.

9. Robertsen B (1999) Modulation of the non-specific defence of fish by structurally Conserved microbial polymers. Fish Shellfish Immunol 9: 269-290.

10. Zhang G, Gong S, Yu D, Yuan H (2009) Propolis and Herba Epidemii extarcts enhance the non-specific immune response and disease resistance of Chinese sucker, Myxocyprinus asiaticus. Fish Shellfish Immunol 26: 467-472. [crossref]

11. Song Z, He C, Fu Z, Shen D (2008) Otolith thermal marking in larval Chinese sucker, Myxocyprinus asiaticus. Environmental Biology of Fishes 82: 1-7.

12. Chunlin H, Zidong F, Danzhou S, B Y,Song Z (2009) Effects of tempreture, starvation and photoperiod on otolith increments in larval Chinese sucker, Myxocyprinus asiaticus. Environmental biology of fishes 84: 159-171.

13. Miller RR (1959) Origin and affinities of the fresh Water fish fauna of western North America. 187-222 in C. L. Hubbs, ed. Zoogeography. Ameri- Can Assoc. For the Advancement of Science.

14. Beamish RJ, Tsuyuki H (2011) A biochemical And cytological study of the longnose sucker (Calostomus calostomus) and large and dwarf forms of the white sucker. J Fish Res Bd Can 28: 1745-1748.

15. Uyeno T, Smith GR (1972) Tetraploid origin of the karyotype of catostomid Gshes Science 175: 644-646. [crossref]

16. Ueno K, Nagase A, Yun-Juan Ye (1988) Tetraploid Origin of the Karyotype of the Asian sucker, Myxocyprinus asiaticus. Japanese Journal of Ichthyology 34: 512-514.

17. Yuan YC, Gong SY, Yang HJ, Lin YC, Yu DH, et al. (2011) Effects of supplementation of crstalline or coated lysine and/or methionine on growth performance and feed utilization of the Chinese sucker, Myxocyprinus asiaticus. Aquaculture 316: 31-36.

18. Yuan YC, Gong SY, Yang HJ, Lin YC, Yu DH, et al. (2010) Apparent digestibility of selected feed ingredients for Chinese sucker, Myxocyprinus asiaticus. Aquaculture 306: 238-243.

19. Vajargah MF (2021) A Review on the Effects of Heavy Metals on Aquatic Animals. J Biomed Res Environ Sci 2: 865-869.

20. Vajargah MF, Sattari M, Namin JI, Bibak M (2021) Predicting the Trace Element Levels in Caspian Kutum (Rutilus kutum) from south of the Caspian Sea Based on Locality, Season and Fish Tissue. Biological Trace Element Research 200: 354-363.

21. Yuan YC, Yang HJ, Gong SY, Luo Z, Yu DH, et al. (2011) Dietary phosphorus requirement of juvenile Chinese sucker, Myxocyprinus asiaticus. Aquaculture Nutrition 17: 159-169.

22. Wan Q, Lai NY, Liu YB, Shen BP, Sun WX, et al. (2006) Study on intensive cultivation of Myxocynricus asiaticus fingerling fed with mixed feed. J. Anhui Agri. Sci 18: 46054606

23. Sattari M, Bibak M, Bakhshalizadeh S, Forouhar Vajargah M (2020) Element accumulations in liver and kidney tissues of some bony fish species in the Southwest Caspian Sea. Journal of Cell and Molecular Research 12: 33-40.

24. Zhang G, Gong S, Yuan Y, Chu Z, Yuan H (2009) Dietary protein reqirement for juvenile Chinese sucker (Myxocyprinus asiaticus). Journal of Applied Ichthyology 25: 715-718. 
25. Forouhar Vajargah M, Imanpoor MR, Shabani A, Hedayati A, Faggio C (2019) Effect of long-term exposure of silver nanoparticles on growth indices, hematological and biochemical parameters and gonad histology of male goldfish (Carassius auratus gibelio). Microscopy research and technique 82: 1224-1230. [crossref]

26. Forster IP, Dominy W, Smiley S, Bechtel P, Hardy R, et al. (2004) Recent advances in utilization of fish by-prod-Ucts in aquaculture feeds. Abstracts Book. Aquaculture 1-5 Honolulu, Hawaii, USA

27. Samocha T, Davis DA, Saoud IP, DeBault K (2004) Sub-Stitution of fish meal by coextruded soybean poultry by-product Meal in practical diets for the Pacific white shrimp, Litopenaeus Vannamei. Aquaculture 231: 197-203.

28. Kristofersson D, Anderson JL (2006) is there a relationship between fisheries and farming Interdependence of fisheries, ani-mal production and aquaculture. Marine Policy 30: 721-725.

29. Vajargah MF, Yalsuyi AM, Hedayati A (2018) Effects of dietary Kemin multi-enzyme on survival rate of common carp (Cyprinus carpio) exposed to abamectin. Iranian J of Marine Sciences 17: 564-572.

30. Montajami S, Vajargah MF, Hajiahmadyan M, Zarandeh HAS, Mirzaie FS, et al. (2012) ASSESSMENT OF THE EFFECTS OF FEEDING FREQUENCY ON GROWTH PERFORMANCE AND SURVIVAL RATE OF TEXAS CICHLID LARVAE (CYANOGUTTATUS HERICHTHYS). J of Fisheries International 7: 51-54.
31. Hajiahmadian M, Vajargah MF, Farsani HG, Chorchi MM (2012) Effect of Spirulina platensis meal as feed additive on growth performance and survival rate in golden barb fish, Punius gelius (Hamilton, 1822). Journal of Fisheries International 7: 61-64.

32. Montajami S, Hajiahmadyan M, Forouhar Vajargah M, Hosseini Zarandeh AS, Shirood Mirzaie F, et al. (2012) Effect of symbiotic (Biomin imbo) on growth performance and survival rate of Texas cichlid (Herichthys cyanoguttatus) larvae. Global Veterinaria 9: 358-361.

33. Yuan YC, Lin YC, Yang HJ, Gong Y, Gong SY, et al. (2012) Evaluation of fermented soybean meal in the practical diets for juvenile Chinese sucke, Myxocyprinus asiaticus. Aquaculture Nutrition 19: 74-83.

34. Hsu T, Shiau S (1998) Comparison of vitamin C require-Ment for maximum growth of grass shrimp, Penaeus mon-Odon, with L-ascorbyl-2-monophosphate-Na and L-ascorbyl-2-monophosphate-Mg. Aquaculture 163: 203-213.

35. Sandell LJ, Daniel JC (1988) Effects of ascorbic acid on collagen mRNA levels in short term chondrocyte Cultures. Connective Tissue Research 17: 11-22. [crossref]

36. Feng Huang, Fan Wu, Song Zhang, Ming Jiang, Wei Liu, et al. (2015) Dietary Vitamin $\mathrm{C}$ requirement of juvenile Chinese sucker, Myxocyprinus asiaticus. Aquaculture research 48 .

\section{Citation:}

Vajargah MF (2021) Introduction to Vital Biological and Regenerative Factors Myxocyprinus asiaticus. Aquac Fish Stud Volume 3(4): 1-3. 